\title{
Plasma Homovanillic Acid: A Significant Association with Alcoholism is Independent of a Functional Polymorphism of the Human Catechol-O-Methyltransferase Gene
}

\author{
Michael D Köhnke*,', Gerlinde Wiatr', Werner Kolb³, Annette M Köhnke', Sandra Schick', Ulrich Lutz', \\ Reinhard Vonthein ${ }^{2}$ and Ines Gaertner' \\ 'University Hospital of Psychiatry and Psychotherapy, Tübingen, Germany; ${ }^{2}$ Department of Medical Biometry, Tübingen University Hospital, \\ Tübingen, Germany; ${ }^{3}$ Wilhelmsheim Hospital, Oppenweiler, Germany
}

\begin{abstract}
The central dopamine system seems to influence addictive disorders. Plasma homovanillic acid (HVA) is an indicator of central dopaminergic activity. In this study the hypothesis that plasma HVA is associated with alcoholism or with delirium tremens (DT) during alcohol withdrawal was tested. A functional genetic polymorphism of the enzyme catechol-O-methyltransferase (COMT) that participates in converting dopamine into its final metabolite HVA was investigated for an association with alcoholism or DT during alcohol withdrawal. In addition, a relation between the functional polymorphism of COMT and plasma HVA concentrations was studied. Plasma HVA concentrations and COMT genotypes were determined in 142 German alcoholics and I0I German healthy controls. Alcoholic patients were examined after a minimum of 3 weeks after cessation of drinking. Mean plasma HVA concentrations were significantly lower in alcoholic patients compared to healthy controls. A group of alcoholics with a history of DT during alcohol withdrawal $(n=62)$ did not differ significantly in plasma HVA concentrations from alcoholics with a history of only mild withdrawal symptoms $(n=67)$. The functional polymorphism of the human COMT gene was neither significantly associated with the diagnosis of alcoholism or DT during alcohol withdrawal nor with plasma HVA concentrations.

Neuropsychopharmacology (2003) 28, 1004-1010, advance online publication, I9 March 2003; doi:I0.1038/sj.npp.1300 I07
\end{abstract}

Keywords: HVA; COMT; alcoholism; polymorphism; HPLC; PCR

\section{INTRODUCTION}

The mesolimbic dopamine system appears to play a critical role in reinforcing alcoholism and in the rewarding effects of alcohol (Mc Bride et al, 1995; Zhou et al, 1995; Nestler et $a l$, 1993; Fujimoto et al, 1983). Dysfunction in dopaminergic transmission has been associated with craving for ethanol (Wise, 1988) and seems to influence withdrawal symptoms (Harris and Aston-Jones, 1994; Heinz et al, 1996).

Dopamine is metabolized into its final metabolite homovanillic acid (HVA) by the action of two enzymes: catechol-O-methyltransferase (COMT) and monoamine oxidase (MAO) (Westerink, 1985; Wood and Altar, 1988). In contrast to HVA in the cerebrospinal fluid (CSF-HVA) plasma HVA is a potential indicator of central dopaminergic neuronal activity (Amin et al, 1992) and can therefore be used as a tool to study the psychopathology of addictive

*Correspondence: Dr Michael D Köhnke, University Hospital of Psychiatry, Osianderstr. 24, 72076 Tübingen, Germany, Tel: +49 707। 29823। I, Fax: +49 707। 294I4I,

E-mail: michael.koehnke@med.uni-tuebingen.de

Received I I April 2002; revised 22 August 2002; accepted 25 October 2002

Online publication: | November 2002 at http: //www.acnp.org/ citations/Npp I I 0102422 disorders. So far only few studies have tried to elucidate the role of HVA in human alcoholism with contradictory results (Heinz et al, 1999; Gabel, 1995; Petrakis et al, 1999; Lappalainen et al, 1999; Fulton et al, 1995; Virkkunen et $a l, 1996)$. Fulton et al (1995) could show in a case control study with a sufficiently large study population that plasma HVA was significantly lower in alcoholic patients $(n=83)$ compared to 69 healthy controls.

Animal testing revealed that altered HVA concentrations in the brain are likely to be determined by at least one gene, which has not been identified yet (Fadda et al, 1991). As potent inhibitors of COMT have been shown to reduce cerebral HVA (Rivas et al, 1999; Brannan et al, 1997; Katajamaki et al, 1998), the COMT gene is a candidate gene for the regulation of HVA concentration.

The polymorphic human COMT gene is located on chromosome 22q11.2. A genetic polymorphism results in three- to four-fold differences in COMT activity (Grossman et al, 1992). Studies that tried to associate the low activity (L) allele of COMT with alcoholism revealed contradictory results (Hallikainen et al, 2000; Tiihonen et al, 1999; Ishiguro et al, 1999; Wang et al, 2001). Men with the LL genotype have shown a significantly higher weekly alcohol consumption than individuals with other genotypes (Kauhanen et al, 2000). 
This study tested if plasma HVA, as an indicator of central dopaminergic activity, or the functional polymorphism of the COMT gene is associated with alcoholism or with delirium tremens (DT) during alcohol withdrawal. It was additionally investigated if the polymorphic COMT gene influences plasma HVA concentrations in a native Western European population.

\section{METHODS AND MATERIALS}

\section{Subjects}

After the study protocol had been approved by the Ethics Committee of the University Hospital of Tübingen, written informed consent was obtained from all participants. All participating individuals were unrelated and of German descent. The present study was designed to compare a group of alcoholic patients with a history of DT to a group of alcoholics suffering only from mild withdrawal symptoms. In addition, all included alcoholic patients were compared with a group of healthy controls. The diagnostic assessment of all individuals was carried out by an interview based on the Structured Clinical Interview for the diagnostic and statistical manual of mental disorders DSM IV (American Psychiatric Association, 1994), SKID (Wittchen et al, 1997). Information about family history, descent, withdrawal symptoms, alcohol, and substance abuse history was obtained and documented. Persons with primary major psychiatric disorders, a history of head trauma and severe medical illnesses, or substance dependence other than alcohol or nicotine dependence were excluded.

Alcoholic patients with a history of DT related to alcohol withdrawal $(n=62)$ were recruited from the detoxification and therapy unit of the Psychiatric University Hospital Tübingen $(n=37)$ and from the Hospital for addictive disorders at Wilhelmsheim $(n=25)$. The patients of this group fulfilled the criteria for alcohol dependence according to the diagnostic and statistical manual of mental disorders (DSM IV) and had a history of alcohol withdrawal DT according to DSM IV that was diagnosed and documented by the treating psychiatrist in the patients chart. This group included eight females and 54 males. The mean age was 46 years (SD: 9; maximum: 63, minimum 27 years).

A total of 67 patients from the alcohol detoxification and therapy unit of the Psychiatric University Hospital Tübingen were included in the group of alcohol-dependent patients with a history of mild withdrawal symptoms. The patients of this group fulfilled the DSM IV criteria for alcohol dependence and had no history of DT or withdrawal seizures. Withdrawal symptoms of this group were documented based on the Clinical Institute Withdrawal Assessment for Alcohol Scale, CIWA-Ar, (Sullivan et al, 1989). Within the first $24 \mathrm{~h}$ of withdrawal, these patients had experienced only mild withdrawal symptoms as defined by a score lower than 12 in the CIWA-Ar (mean: 1.1; SD: 2.4; maximum: 11, minimum: 0). This group included 19 females and 48 males. The mean age was 41 years (SD: 7.8; maximum: 61, minimum: 27 years). Most of the individuals of this group took no medication affecting withdrawal symptoms $(n=52)$. Of these, 15 patients received clomethiazol to relieve milder symptoms of with- drawal, with a mean dosage of $1.0 \mathrm{~g}$ (SD: $0.6 \mathrm{~g}$ ) during the first $24 \mathrm{~h}$.

The group of alcohol-dependent patients $(n=142)$ consists of all the included patients with mild withdrawal symptoms and with a history of DT. In all, 13 additional alcohol-dependent patients according to DSM IV, who suffered from more severe withdrawal symptoms (CIWA-Ar score $\geqslant 12$ ), but did not have a history of DT and could therefore not be assigned to any of the other groups were added to compare this group of alcohol-dependent patients with healthy controls. The total group of alcoholics included 29 females and 113 males. The mean age was 43.6 years (SD: 8.5; maximum: 63 , minimum: 21 years).

A total of 101 healthy and unrelated controls of German descent were recruited in the greater Stuttgart area in southwest Germany. Individuals receiving psychotropic drugs, individuals with a psychiatric disorder according to DSM IV criteria including problems with substance abuse or addiction (other than nicotine) or with a positive family history for addiction or other psychiatric disorders were not included. Individuals had to be at least 24 years old. This group included 36 females and 65 males. The mean age was 37.4 years (SD: 10.7; maximum: 62, minimum: 24 years).

\section{Determination of HVA in Plasma}

Blood samples were obtained for plasma HVA determination from all 243 individuals. None of the participating subjects took psychotropic medication. Each sample was obtained by venipuncture between 7:00 and 8:00 am after an overnight fast. The blood was centrifuged within $30 \mathrm{~min}$ and the plasma was stored at $-20^{\circ} \mathrm{C}$ until analysis.

Plasma $(0.6 \mathrm{ml})$ was mixed with $0.7 \mathrm{ml}$ of $0.1 \mathrm{M} \mathrm{NaCl}$ and $0.2 \mathrm{ml}$ of $10 \mathrm{~N} \mathrm{HCl}$ was added under vigorous shaking. After further shaking for $30 \mathrm{~min}$, precipitated proteins were sedimented by centrifugation at $11000 \mathrm{rpm}$ for $20 \mathrm{~min}$. From $1.2 \mathrm{ml}$ of the supernatant, HVA was extracted three times with $1.5 \mathrm{ml}$ of tert-butyl methyl ether. The combined organic phases were evaporated under a stream of nitrogen and the residue was dissolved in $0.4 \mathrm{ml}$ of $1 \mathrm{mM} \mathrm{Na}_{2}$-EDTA. The extracts were stable for up to 3 days when frozen in liquid nitrogen and stored at $-80^{\circ} \mathrm{C}$.

HPLC analysis was carried out on a $150 \times 4 \mathrm{~mm}^{2}$ column with GROM-SIL 120 ODS-4HE $5 \mu \mathrm{m}$ (GROM Analytik, Herrenberg, Germany), the eluent containing $78 \% 50 \mathrm{mM}$ $\mathrm{KH}_{2} \mathrm{PO}_{4}$ adjusted to $\mathrm{pH} 3$ with $\mathrm{H}_{3} \mathrm{PO}_{4}+5 \mathrm{mM} \mathrm{KCl}, 11 \%$ methanol and $11 \%$ acetonitrile, flow rate $0.9 \mathrm{ml} / \mathrm{min}$, temperature $35^{\circ} \mathrm{C}$, injected volume $0.1 \mathrm{ml}$, retention time of HVA $6.6 \mathrm{~min}$. The eluate was monitored by an HP 1049A electrochemical detector with a glassy carbon working electrode set at $+0.7 \mathrm{~V}$. For a reproducible response, the electrode was purified in the pretreat mode by six cycles of +1.0 and $-0.4 \mathrm{~V}$ prior to each analysis. Quantification was based on peak heights relative to those of external standards. An aqueous solution of $1 \mathrm{mM}$ HVA was stable for at least 9 months at $-20^{\circ} \mathrm{C}$. It was diluted with eluent to concentrations of $0.6-6 \mathrm{ng} / 0.1 \mathrm{ml}$ for calibration curves run with each series, which went through the origin. For recovery experiments, plasma with a low HVA level was spiked with 7-22 ng HVA/0.6 ml resulting in a recovery of 97.9\% (SD: $2.7 \% ; N=25)$. All plasma samples from patients and controls and additional 66 samples (independent from 
this study) were analyzed in duplicate with a coefficient of variation of $13 \%(N=309)$. The limit of detection at a signal/noise ratio of 5 was $0.2 \mathrm{ng}$ per injection equivalent to $1.4 \mathrm{ng} / \mathrm{ml}$ plasma.

\section{Genotyping}

Genomic DNA was isolated from all participants of the study using standard procedures (Miller et al, 1988). Specific PCR primers for the functional COMT polymorphism were used as previously described (Daniels et al, 1996):

COMT-1s: 5'-ACT GTG GCT ACT CAG CTG TG-3'

COMT-1a: $5^{\prime}$-CCT TTT TCC AGG TCT GAC AA- $3^{\prime}$.

PCR reactions were run in a total volume of $21 \mu \mathrm{l}$ and contained $2.5 \mathrm{mM} \mathrm{MgCl} 2,0.25 \mathrm{mM}$ of each dNTP, $1.5 \mathrm{U}$ of Taq DNA polymerase (Gibco-BRL), a $1 \times$ PCR-buffer as supplied by the manufacturer, $0.5 \mu \mathrm{M}$ of each primer and $25 \mathrm{ng}$ of genomic DNA. PCR assays were performed with 35 cycles with denaturation at $94^{\circ} \mathrm{C}$ for $45 \mathrm{~s}$, annealing at $60^{\circ} \mathrm{C}$ for $60 \mathrm{~s}$ and extension at $72^{\circ} \mathrm{C}$ for $60 \mathrm{~s}$. Aliquots of the reaction mix $(7 \mu \mathrm{l})$ were digested for at least $4 \mathrm{~h}$ at $37^{\circ} \mathrm{C}$ with $5 \mathrm{U}$ of NIaIII (New England Biolabs) in a final volume of $17 \mu$ l. The digested products were separated on $3 \%$ agarose gels with direct visualization with ethidium bromide under UV-light. A 100 base-pair ladder (Gibco-BRL) was used for the estimation of fragment sizes. The digested 169-bp PCR product yielded a 114-bp product for the $\mathrm{H}$ activity (Val158) allele and a 96-bp fragment for the L activity (158Met) allele.

\section{Statistical Analysis}

For parametric analyses, we employed a logarithmic transformation of plasma HVA. A Box-Cox analysis suggested this, and it resulted in homoskedastic, normaldistributed residuals, which was verified by a normal quantile plot (not shown). Genotype/phenotype data were analyzed using one- and two-way ANOVA. Pairs of groups were compared using $t$-tests.

Allelic and genotypic frequencies were compared between groups using $2 \times 2$ and $2 \times 3$ contingency tables, odds ratios with exact confidence limits (CI) and Fisher's exact test or an extended version thereof, respectively. A significance level of 5\% was chosen for type 1 error. A correction for multiple testing was not performed.

Deviations from Hardy-Weinberg equilibrium (HWE) were assessed using the HWSIM program (Cubells et al, 1997).

\section{RESULTS}

\section{Plasma HVA}

Logarithmically transformed plasma HVA was significantly lower in the group of 142 alcohol-dependent patients compared with 101 healthy controls ( $t$-test: $p=0.002$; Table 1). The geometric mean in alcoholics was $11.7 \mathrm{ng} / \mathrm{ml}$ (coefficient of variation (CV): $54 \%$; range 5-44) compared to $14.1 \mathrm{ng} / \mathrm{ml}$ (CV: $48 \%$; range $6-37$ ) in healthy controls.

The geometric mean plasma HVA was $11.8 \mathrm{ng} / \mathrm{ml}(\mathrm{CV}$ : $53 \%$; range 5-30) in subjects with a history of DT $(n=62)$
Table I Plasma HVA Levels (in $\mathrm{ng} / \mathrm{ml}$ ) after at least 22 Days after Cessation of Drinking in 142 Alcoholics Compared to 101 Healthy Controls

\begin{tabular}{lcc}
\hline & Alcoholics & Healthy controls \\
\hline $\mathrm{N}$ & 142 & 101 \\
Plasma HVA $(\mathrm{ng} / \mathrm{ml})$ & $5-44$ & $6-37$ \\
Range & 11.5 & 14 \\
Median $^{\text {a }}$ & $9-16$ & $11-19$ \\
Interquartile range $^{-16}$ & \\
\hline
\end{tabular}

aPlasma HVA levels were significantly lower in the groups of alcoholics; $t$-test after logarithmic transformation of plasma HVA $(p=0.002)$.

Table 2 Plasma HVA Levels (in $\mathrm{ng} / \mathrm{ml}$ ) after at least 22 Days After Cessation of Drinking in 62 Alcoholics with a History of DT Compared to 67 Alcoholics with only Mild Withdrawal Signs (MWS)

\begin{tabular}{|c|c|c|}
\hline & $\begin{array}{c}\text { DT } \\
\text { alcoholics }\end{array}$ & $\begin{array}{l}\text { MWS } \\
\text { alcoholics }\end{array}$ \\
\hline $\begin{array}{l}\text { N } \\
\text { Plasma HVA }(n g / m l)\end{array}$ & 62 & 67 \\
\hline Range & $5-30$ & $5-33$ \\
\hline Median $^{\mathrm{a}}$ & 12 & |1 \\
\hline Interquartile range & $9-16$ & $9-15$ \\
\hline
\end{tabular}

and $11.7 \mathrm{ng} / \mathrm{ml}(\mathrm{CV}: 49 \%$; range 5-33) in patients with a history of mild withdrawal symptoms $(n=67)$. No significant difference in plasma HVA was found comparing these two groups (Table 2) ( $t$-test after logarithmic transformation of plasma HVA: $p=0.97)$.

\section{COMT: Allelic and Genotypic Frequencies}

Of the 243 individuals that were genotyped for the COMT polymorphism, 71 carried the homozygous LL genotype $(\mathrm{f}(\mathrm{LL})=0.29), 114$ the HL $(\mathrm{f}(\mathrm{HL})=0.47)$, and 58 the $\mathrm{HH}$ genotype $(\mathrm{f}(\mathrm{HH})=0.24)$. For both the total group and the healthy control subgroup, genotype frequencies did not deviate significantly from $\operatorname{HWE}(p>0.3$ in all cases).

No significant differences in allelic or genotypic distribution of COMT were found between alcoholics with a history of DT and alcoholics with a history of mild withdrawal symptoms ( $p=0.53$ and 0.80 , respectively) or between alcoholics and healthy controls $(p=0.49$ and 0.65 , respectively) (Table 3 ). The odds ratio for allele $\mathrm{L}$ was 0.86 (CI: 0.49-1.39) when comparing DT with MWS alcoholics. The odds ratio for allele L was 1.09 (CI: 0.75 -1.59) when comparing all alcoholics with healthy controls.

\section{COMT Genotype and Plasma HVA}

Data on plasma HVA and COMT genotypes were available from all 243 individuals, consisting of 142 alcoholics and 
Table 3 Genotype and Allele Frequency of the COMT Polymorphism in Patients with Alcohol Addiction and Control Subjects

\begin{tabular}{|c|c|c|c|c|c|c|}
\hline \multirow[b]{2}{*}{ Sample } & \multirow[b]{2}{*}{$n$} & \multicolumn{3}{|c|}{ Genotype frequency } & \multicolumn{2}{|c|}{ Allele frequency } \\
\hline & & $\begin{array}{c}\mathbf{H} / \mathbf{H} \\
(\%)\end{array}$ & $\begin{array}{l}\mathbf{H} / \mathbf{L} \\
(\%)\end{array}$ & $\begin{array}{l}\text { L/L } \\
\text { (\%) }\end{array}$ & $\begin{array}{c}\mathbf{H} \\
(\%)\end{array}$ & $\begin{array}{l}\mathbf{L} \\
(\%)\end{array}$ \\
\hline Alcoholics (MWS) & 67 & 24 & 48 & 28 & 48 & 52 \\
\hline Alcoholics (DT) & 62 & 27 & 50 & 23 & 52 & 48 \\
\hline Alcoholics (total) ${ }^{\mathrm{a}}$ & 142 & 23 & 50 & 27 & 48 & 52 \\
\hline Control subjects & 101 & 25 & 43 & 32 & 46 & 54 \\
\hline
\end{tabular}

Alcoholics (total) vs control subjects: genotype, $p=0.49$; allele, $p=0.65$. DT alcoholics vs MWS alcoholics: genotype, $p=0.80$; allele, $p=0.53$.

${ }^{a}$ Total $n$ includes 13 alcoholics not otherwise specified.

DT, delirium tremens; MWS, mild withdrawal symptoms.

Table 4 Plasma HVA (in $\mathrm{ng} / \mathrm{ml}$ ) in a Sample of 243 German Individuals, Consisting of I 42 Alcoholics and I0I Healthy Controls, Grouped According to COMT Genotypes

\begin{tabular}{|c|c|c|c|}
\hline Genotype & HH & HL & LL \\
\hline $\begin{array}{l}N \\
\text { Plasma HVA }(\mathrm{ng} / \mathrm{ml})\end{array}$ & 58 & 114 & 71 \\
\hline Range & $6-37$ & $5-44$ & $5-29$ \\
\hline Median ${ }^{\mathrm{a}}$ & 13 & 12 & 12 \\
\hline Interquartile range & $10-18.5$ & $9.75-16$ & $9-19$ \\
\hline
\end{tabular}

aStatistical analysis revealed no significant effect of COMT genotype on plasma HVA (ANOVA after logarithmic transform: $p=0.36$ )

101 healthy controls (Table 4). There was no significant association of genotype and plasma HVA (one-way ANOVA: $p=0.36)$. Analyzing only healthy controls revealed similar results (data not shown).

In a two-way ANOVA explaining HVA levels by health status, COMT genotype and their interaction, this interaction was not significant $(p=0.78)$. Results for the main effects were as before: a significant difference between alcoholics and controls $(p=0.01)$, but not between COMT genotypes $(p=0.39)$.

\section{DISCUSSION}

The major finding of the present study is that mean plasma HVA concentrations were significantly lower in the included abstinent alcoholic patients compared to healthy controls. A group of alcoholics with a history of DT during alcohol withdrawal did not differ in plasma HVA concentrations from alcoholics with a history of only mild withdrawal symptoms. The functional polymorphism of the human COMT gene was neither significantly associated with the diagnosis of alcoholism or DT during alcohol withdrawal nor with plasma HVA concentrations.

In this study, plasma HVA was chosen as an indicator for central dopaminergic activity. HVA measurement in plasma is considered the most convenient and potentially useful indicator of central dopamine neural activity (Amin et al, 1992). In contrast to plasma HVA it is unclear whether CSF
HVA can reflect cortical dopaminergic neural activity, since HVA from most regions of the brain seems to enter directly into blood circulation without ever appearing in CSF (Neff et al, 1967; Meek and Neff, 1973; Aizenstein and Korf, 1978). The mean half-life of plasma HVA in humans appears to be $1 \mathrm{~h}$ (Anggard et al, 1974; Elchisak et al, 1982). It is mainly renally excreted (Elchisak et al, 1979). The effect of diet on plasma HVA lasts several hours, but overnight fasting eliminates the dietary effects on plasma HVA concentrations in humans (Davidson et al, 1987; Elsworth et al, 1987).

Alterations of the dopaminergic system during early alcohol withdrawal have been shown (Heinz et al, 1996; Uzbay et al, 1998). A decreased plasma HVA 3 weeks after cessation of drinking could be explained by the prior withdrawal only if the effects of the acute withdrawal were long lasting. This is unlikely taking the results of Sano et al (1992) into consideration, who could show that alcoholics without DT recovered within 2 weeks from the direct effects of withdrawal on plasma HVA. In the present study, the risk of a sampling bias was minimized as all individuals had normal renal function and were free of psychotropic medication at the time of sample collection, and possible influences of circadian variations, dietary amines, and orthostatic changes were avoided by collecting samples after an overnight fast between 7:00 and 8:00 am at rest.

This study shows that mean plasma HVA was significantly lower in a group of alcoholics after a minimum of 3 weeks of abstinence compared with plasma HVA in healthy controls. These findings are in accordance with the results of one other study on plasma HVA in abstinent alcoholics (Fulton et al, 1995), whereas studies on alcoholism examining CSF HVA instead of plasma HVA produced inconsistent results (Heinz et al, 1999; Petrakis et al, 1999; Lappalainen et al, 1999; Virkkunen et al, 1996), most likely caused by the difficulties of determining central HVA concentrations through HVA in CSF.

Future prospective studies should try to further elucidate the cause of the alteration of HVA in alcoholics and whether it can be used as a trait marker for alcoholism. The findings however make it difficult to believe that plasma HVA will be used as a reliable trait marker to predict the individual risk for alcohol addiction since a broad range of plasma HVA of $5-44 \mathrm{ng} / \mathrm{ml}$ in alcoholics and 6-37 ng/ml in healthy controls was determined.

It remains unclear whether smoking contributed to the observed group differences in plasma HVA concentration as the smoking status of the individuals was not recorded. Recent studies (Salminen and Ahtee, 2000; Kiianmaa et al, 2000) have shown that chronic intake of nicotine does not influence striatal and plasma HVA concentration in rodents suggesting only little influence of smoking status on the results of the present study. However, on the background of conflicting results of some prior studies revealing altered HVA concentrations caused by the intake of nicotine (Pietila et al, 1995; Geracioti et al, 1999), the issue should be investigated further in future studies.

Also a toxic influence of alcohol on catecholaminergic neurons, which has been described by Arango et al (1994) in a post-mortem study, could alternatively be the cause for the observed alteration in plasma HVA concentration. It is unlikely that the acute withdrawal is an explanation for the 
observed differences in plasma HVA since all alcoholics maintained sober for a sufficient time prior to inclusion. The results of Sano et al (1992) that showed a significantly $(p<0.01)$ elevated plasma HVA in alcoholics with DT $(n=5) 22$ days after cessation of drinking, but who lack statistical power because of small numbers, were not replicated in the present study, suggesting that plasma HVA is not a trait marker for DT during alcohol withdrawal.

COMT exists in a low activity and a high activity form, which is caused by an exonic polymorphism of the COMT gene that is located on chromosome 22q 11.2, changing Met to $\mathrm{Val}$ at positions 108 and 158 in the enzyme (Boudikova et al, 1990; Grossman et al, 1992; Klemetsdal et al, 1994; Lachman et al, 1996). A study on a Finn population revealed that the COMT genotype contributed significantly to alcohol intake, not only in alcoholics but also in the general population. The low activity genotype (LL) of COMT was associated with an elevated alcohol consumption (Kauhanen et al, 2000). Other studies on the effects of the COMT genotype on alcoholism have presented contradictory results (Wang et al, 2001; Hallikainen et al, 2000; Tiihonen et al, 1999; Ishiguro et al, 1999). The present study tried to associate the COMT gene with alcoholism and for the first time with DT during alcohol withdrawal. The results suggest that there is no major effect of the COMT genotype on the diagnosis of alcoholism or on severe alcohol withdrawal with DT. Odds ratios however were low (1.0 and 0.86 , respectively). A negative association can also be caused by heterogeneous groups. In this study we tried to avoid heterogeneity by inclusion of only German individuals and by examining homogeneous subgroups of alcoholics precisely defined by withdrawal symptoms. However the chosen criteria cannot differentiate between other phenotypes like Cloninger's subtypes of alcoholism resulting in heterogeneous subgroups as far as personality traits are concerned. The group that consists of all alcoholics of the different subgroups and was compared to healthy subjects is certainly not homogenous except for the criteria of alcohol addiction as defined by DSM IV.

The genetic background of alcoholism is most likely polygenetic with other genes being of greater importance than the COMT gene. The task of future trials should be to focus on other functional polymorphisms possibly combining them in a haplotype analysis examining larger numbers of subjects.

Since the enzyme COMT contributes to the metabolism of dopamine into HVA and potent inhibitors of COMT as Entacapone, dinitrocatechol, and Ro-41-0960 have been shown to reduce cerebral HVA (Rivas et al, 1999; Brannan et al, 1997; Katajamaki et al, 1998), the functional COMT gene is likely to influence the levels of HVA. The genes of several dopamine receptors, the human tryptophan hydroxylase gene and the COMT gene however did not show an effect on CSF-HVA (Goldman et al, 1992; Adamson et al, 1995; Jönsson et al, 1997), which in contrast to plasma HVA is unlikely to reflect cortical dopaminergic neural activity (Neff et al, 1967; Meek and Neff, 1973; Aizenstein and Korf, 1978). The only trial that studied the effect of entacapone on plasma HVA however showed no significant alteration (Keranen et al, 1993).

The results of the present study suggest that the functional polymorphism of COMT alone will not become rate limiting in the formation of plasma HVA. One promising approach to the genetic background of HVA levels in future trials could be the utilization of a haplotype analysis including other candidate genes linked to the dopamine system like the MAO-A gene.

\section{ACKNOWLEDGMENTS}

This study was financially supported by the 'fortüne-fund' (project 490) of Tübingen University, Germany. We thank Professor Dr Ursula Breyer-Pfaff of the Institute of Toxicology of Tübingen University for her advice in establishing the HPLC Method to detect plasma HVA.

\section{REFERENCES}

Adamson MD, Kennedy J, Petronis A, Dean M, Virkkunen M, Linnoila $\mathrm{M}$ et al (1995). DRD4 dopamine receptor genotype and CSF monoamine metabolites in Finnish alcoholics and controls. Am J Med Genet 60: 199-205.

Aizenstein ML, Korf J (1978). Aspects of influx and efflux of homovanillic acid of rat cerebrospinal fluid. Brain Res 149: 129140.

Amin F, Davidson M, Davis KL (1992). Homovanillic acid measurement in clinical research: a review of methodology. Schizophr Bull 18: 123-148.

Anggard E, Lewander T, Sjoquist B (1974). Determination of homovanillic acid turnover in man. Life Sci 15: 111-122.

Arango V, Underwood MD, Mann JJ (1994). Fewer pigmented neurons in the locus coeruleus of uncomplicated alcoholics. Brain Res 650: 1-8.

Boudikova B, Szumlanski C, Maidak B, Weinshilboum R (1990). Human liver catechol- $O$-methyltransferase pharmacogenetics. Clin Pharmacol Ther 48: 381-389.

Brannan T, Prikhojan A, Yahr MD (1997). Peripheral and central inhibitors of catechol-O-methyl transferase: effects on liver and brain COMT activity and L-DOPA metabolism. J Neural Transm 104: 77-87.

Cubells JF, Kobayashi K, Nagatsu T, Kidd KK, Kidd JR, Calafell F et al (1997). Population genetics of a functional variant of the dopamine beta-hydroxylase gene (DBH). Am J Med Genet 74: 374-379.

Daniels JK, Williams NM, Williams J, Jones LA, Cardno AG, Murphy KC et al (1996). No evidence for allelic association between schizophrenia and a polymorphism determining high or low catechol-O-methyltransferase activity. Am J Psychiatry 153: 268-270.

Davidson M, Giordani AB, Mohs RC, Mykytyn VV, Platt S Aryan ZS et al (1987). Control of exogenous factors affecting plasma homovanillic acid concentration. Psychiatry Res 20: 307-312.

Elchisak MA, Polinsky RJ, Ebert MH, Kopin IJ (1982). Kinetics of homovanillic acid and determination of its production rate in humans. J Neurochem 38: 380-385.

Elchisak MA, Polinsky RJ, Ebert MH, Modlin LT, Kopin IJ (1979). Kinetics of homovanillic acid and determination of its production rate in the rhesus monkey. Life Sci 24: 1493-1502.

Elsworth JD, Leahy DJ, Roth RH, Redmond DE (1987). Homovanillic acid concentrations in brain, CSF and plasma as indicators of central dopamine function in primates. $J$ Neural Transm 68: 51-62.

Fadda F, Colombo G Gessa GL (1991). Genetic sensitivity to effect of ethanol on dopaminergic system in alcohol preferring rats. Alcohol Alcohol 1(Suppl.): 439-442. 
Fujimoto A, Nagao T, Ebara T, Sato M, Otsuki S (1983). Cerebrospinal fluid monoamine metabolites during alcohol withdrawal syndrome and recovered state. Biol Psychiatry 18: 1141-1152.

Fulton MK, Kramer G, Moeller FG, Chae Y, Isbell PG, Petty F (1995). Low plasma homovanillic acid levels in recently abstinent alcoholic men. Am J Psychiatry 152: 1819-1820.

Gabel S (1995). Homovanillic acid and dopamine- $\beta$-hydroxylase in male youth: relationships with paternal substance abuse and antisocial behavior. Am J Drug Alcohol Abuse 21: 363-378.

Geracioti TD, West SA, Baker DG, Hill KK, Ekhator NN, Wortman $\mathrm{MD}$ et al (1999). Low CSF concentration of a dopamine metabolite in tobacco smokers. Am J Psychiatry 156: 130-132.

Goldman D, Dean M, Brown GL, Bolos AM, Tokola R, Virkkunen $M$ et al (1992). D2 dopamine receptor genotype and cerebrospinal fluid homovanillic acid, 5-hydroxyindoleacetic acid and 3methoxy-4-hydroxyphenylglycol in alcoholics in Finland and the United States. Acta Psychiatr Scand 86: 351-357.

Grossman MH, Emanuel BS, Budarf ML (1992). Chromosomal mapping of the human catechol- $O$-methyltransferase gene to 22q11.1-q11.2. Genomics 12: 822-825.

Hallikainen T, Lachman H, Saito T, Volavka J, Kauhanen J, Salonen JT et al (2000). Lack of association between the functional variant of the catechol-O-methyltransferase (COMT) gene and early-onset alcoholism associated with severe antisocial behavior. Am J Med Genet 96: 348-352.

Harris GC, Aston-Jones G (1994). Involvement of D2 dopamine receptors in the nucleus accumbens in opiate withdrawal syndrome. Nature 371: 155-157.

Heinz A, Schmidt K, Baum SS, Kuhn S, Dufeu P, Schmidt LG et al (1996). Influence of dopaminergic transmission on severity of withdrawal syndrome in alcoholism. J Stud Alcohol 57: 471474

Heinz A, Weingartner H, George D, Hommer D, Wolkowitz OM, Linnoila M (1999). Severity of depression in abstinent alcoholics is associated with monoamine metabolites and dehydroepiandrosterone-sulfate concentrations. Psychiatry Res 89: 97-106.

Ishiguro H, Haruo-Shibuya T, Toru M, Saito T, Arinami T (1999). Association study between high and low activity polymorphism of catechol-O-methyltransferase gene and alcoholism. Psychiatr Genet 9: 135-138.

Jönsson EG, Goldman D, Spurlock G, Gustavsson JP, Nielsen DA, Linnoila $\mathrm{M}$ et al (1997). Tryptophan hydroxylase and catechol$O$-methyltransferase gene polymorphisms: relationships to monoamine metabolite concentrations in CSF of healthy volunteers. Eur Arch Psychiatry Clin Neurosci 247: 297-302.

Katajamaki J, Honkanen A, Piepponen TP, Linden IB, Zharkovsky A, Ahtee L (1998). Conditioned place preference induced by a combination of L-dopa and a COMT inhibitor, entacapone, in rats. Pharmacol Biochem Behav 60: 23-26.

Kauhanen J, Hallikainen T, Tuomainen TP, Koulu M, Karvonen MK, Salonen JT et al (2000). Association between the functional polymorphism of catechol-O-methyltransferase gene and alcohol consumption among social drinkers. Alcohol Clin Exp Res 24: 135-139.

Keranen T, Gordin A, Harjola VP, Karlsson M, Korpela K, Pentikainen PJ et al (1993). The effect of catechol-O-methyl transferase inhibition by entacapone on the pharmacokinetics and metabolism of levodopa in healthy volunteers. Clin Neuropharmacol 16: 145-156.

Kiianmaa K, Tuomainen P, Makova N, Seppa T, Mikkola JA, Petteri-Pepponen $\mathrm{T}$ et al (2000). The effects of nicotine on locomotor activity and dopamine overflow in the alcoholpreferring AA and alcohol-avoiding ANA rats. Eur J Pharmacol 407: 293-302.

Klemetsdal B, Straume B, Giverhaug T, Aarbakke J (1994). Low catechol-O-methyltransferase activity in a Saami population. Eur J Clin Pharmacol 46: 231-235.
Lachman HM, Papolos DF, Saito T, Yu YM, Szumlanski CL, Weinshilboum RM (1996). Human catechol-O-methyltransferase pharmacogenetics : description of a functional polymorphism and its potential application to neuropsychiatric disorders. Pharmacogenetics 6: 243-250.

Lappalainen J, Long JC, Virkkunen M, Ozaki N, Goldman D, Linnoila M (1999). HTR2C Cys23Ser polymorphism in relation to CSF monoamine metabolite concentrations and DSM-III-R psychiatric diagnoses. Biol Psychiatry 46: 821-826.

McBride WJ, Bodart B, Lumeng L, Li TK (1995). Association between low contents of dopamine and serotonin in the nucleus accumbens and high alcohol preference. Alcohol Clin Exp Res 19: $1420-1422$.

Meek JL, Neff NH (1973). Is cerebrospinal fluid the major avenue for the removal of 5-hydroxyindoleacetic acid from the brain? Neuropharmacology 12: 497-499.

Miller SA, Dykes DD, Polesky HF (1988). A simple salting out procedure for extracting DNA from human nucleated cells. Nucleic Acids Res 16: 1215.

Neff NH, Tozer TN, Brodie BB (1967). Application of steady state kinetics to studies of the transfer of 5-hydroxyindoleacetic acid from brain to plasma. J Pharmacol Exp Ther 158: 214-218.

Nestler EJ, Hope BT, Widnell KL (1993). Drug addiction: a model for the molecular basis of neural plasticity. Neuron 11: 995-1006.

Petrakis IL, Trevisan L, D'Souza C, Gil R, Krasnicki S, Webb E et al (1999). CSF monoamine metabolite and beta endorphin levels in recently detoxified alcoholics and healthy controls: prediction of alcohol cue-induced craving? Alcohol Clin Exp Res 23: 13361341.

Pietila K, Laakso I, Ahtee L (1995). Chronic oral nicotine administration affects the circadian rhythm of dopamine and 5-hydroxytryptamine metabolism in the striata of mice. Naunyn Schmiedeberg's Arch Pharmacol 353: 110-115.

Rivas E, de Ceballos ML, Nieto O, Fontenla JA (1999). In vivo effects of new inhibitors of catechol-O-methyl transferase. $\mathrm{Br} J$ Pharmacol 126: 1667-1673.

Salminen O, Ahtee L (2000). The effects of acute nicotine on the body temperature and striatal dopamine metabolism of mice during chronic nicotine infusion. Neurosci Lett 284: 37-40.

Sano H, Suzuki Y, Ohara K, Yazaki R, Ishigaki T, Yokoyama T et al (1992). Circadian variation in plasma homovanillic acid level during and after alcohol withdrawal in alcoholic patients. Alcohol Clin Exp Res 16: 1047-1051.

Sullivan JT, Sykora K, Schneiderman J, Naranjo CA, Sellers EM (1989). Assessment of alcohol withdrawal: the revised clinical institute withdrawal assessment for alcohol scale (CIWA-Ar). $\mathrm{Br}$ J Addict 84: 1353-1357.

Tiihonen J, Hallikainen T, Lachman H, Saito T, Volavka J, Kauhanen J et al (1999). Association between the functional variant of the catechol-O-methyltransferase (COMT) gene and type 1 alcoholism. Mol Psychiatry 4: 286-289.

Uzbay IT, Usanmaz SE, Tapanyigit EE, Aynacioglu S, Akarsu ES (1998). Dopaminergic and serotonergic alterations in the rat brain during ethanol withdrawal: association with behavioral signs. Drug Alcohol Depend 53: 39-47.

Virkkunen M, Eggert M, Rawlings R, Linnoila M (1996). A prospective follow-up study of alcoholic violent offenders and fire setters. Arch Gen Psychiatry 53: 523-529.

Wang T, Franke P, Neidt H, Cichon S, Knapp M, Lichtermann D et al (2001). Association study of the low-activity allele of catechol$O$-methyltransferase and alcoholism using a family-based approach. Mol Psychiatry 6: 109-111.

Westerink BHC (1985). Sequence and significance of dopamine metabolism in rat brain. Neurochem Int 7: 221-227.

Wise RA (1988). The neurobiology of craving: implications for the understanding and treatment of addiction. J Abnorm Psychol 97: 118-132. 
Wittchen HU, Zaudig M, Fydrich T (1997). SKID. Strukturiertes Klinisches Interview fuer DSM-IV (Users Guide for the Structured Clinical Interview for DSM-IV, modified version), (Original: First MB, Gibbon M, Spitzer, RL, Williams JBW (1996). SCID-I; SCID-II); Testzentrale, Robert-Bosch-Breite 25, D-37079 Goettingen.
Wood PL, Altar CA (1988). Dopamine release in vivo from nigrostriatal, mesolimbic, and mesocortical neurons: utility of 3-methoxytyramine measurements. Pharmacol Rev 40: 163-187.

Zhou FC, Zhang JK, Lumeng L, Li TK (1995). Mesolimbic dopamine system in alcohol-preferring rats. Alcohol 12: 403-412. 